\title{
Sayısal Jeoloji İle Benzer Bej Kireçtaşı Mostralarının Tespiti: Eğirdir Örneği
}

\author{
Kubilay UYSAL ${ }^{* 1}$ (1), Yunus Emre YILMAZ2 ${ }^{2}$ (1) \\ 1,2Süleyman Demirel Üniversitesi, Mühendislik Fakültesi, Jeoloji Mühendisliği Bölümü, 32260, Isparta, Türkiye
}

(Alınış / Received: 25.01.2019, Kabul / Accepted: 03.07.2019, Online Yayınlanma / Published Online: 30.12.2019)

Anahtar Kelimeler
Mermer,
Eğirdir,
Sayısal,
Jeoloji,
CBS,
Uzaktan algllama

\begin{abstract}
Özet: Çalışma, örnek olarak seçilen Eğirdir (Isparta) ilçesi dolaylarında yayılım sunan bej renkli kireçtaşı mostralarının sayısal özelliklerinin ortaya konmasını ve benzer kireçtaşı mostralarının sayısal jeolojik yöntemler ile tespit edilerek tüm araştırmanın saha verileri ile doğrulanmasını kapsamaktadır. Çalışmada 16 farklı bej mermer ocak alanın sayısal özellikleri ortaya konmuştur. Bu özellikler Morfoloji, Drenaj, Çizgisellik ve Landsat uydu görüntülerinden elde edilen çeşitli sınıflama değerleridir. Elde edilen sayısal verilerde yapılan sınıflama ve süzgeç çalışmaları sonucunda, ocak sahalarında işletme öncesi ve sonrasına ait veriler değerlendirilerek mevcut ocak yerlerinin ve bunlara benzer başka sahaların tespit edilebilir olduğu ortaya konmuştur. Varlığı sayısal jeolojik verilerin değerlendirilmesi ile tespit edilen benzer bej kireçtaşı mostralarından bazılarında yerinde tespit ile doğrulama yapılmıştır.
\end{abstract}

\section{Detection of Similar Beige Limestone Outcrops with Digital Geology: Eğirdir Example}

\author{
Keywords \\ Marble, \\ Eğirdir, \\ Digital, \\ Geology, \\ GIS, \\ Remote sensing
}

\begin{abstract}
The study covers the digital properties of beige limestone outcrops which are spreading around Eğirdir (Isparta) district which is chosen as an example and also confirming existence of similar limestone outcrops with field works. In this study, the digital geologic properties of the areas covered by 16 different beige marble quarries were revealed. These properties are morphology, drainage, linearity and various classification values obtained from Landsat satellite images. As a result of the classification and filtering studies carried out in the digital geological data obtained from quarries, it was revealed that the existing quarries and similar beige limestone outcrops are detectable. In addition, the presence of similar limestone outcrops in many different locations within the study area was determined and some of them were verified by on-site investigation.
\end{abstract}

\section{Giriş}

$\mathrm{Bu}$ çalışmada mermercilikte jeolojinin önemi ve jeoloji biliminde sayısal (dijital) tekniklerin kullanımı ele alınmıştır. Çalışma, Eğirdir dolaylarından seçilen mermercilik bölgesindeki bej renkli kireçtaşı (mermer: Ottoman beji) mostralarının özelliklerinin bilgisayar ortamında analiz edilmesini, benzer mostraların tespitini ve araştırmanın saha verileri ile desteklenmesini kapsamaktadır.

Sayısal (dijital) jeoloji akademik olarak bu çalışma ile ortaya atılmış yenilikçi bir kavramdır. Bu kavram ülkemizde "sayısal jeoloji haritaları" ve "CBS-Coğrafi Bilgi Sistemleri" olarak düşünülse de, yapısal ölçümler, sondaj verileri, zamana bağlı değişimler, yerinde yapılan ölçümler, minerolojik-petrografik özellikler, hidrojeolojik ölçümler, jeokimyasal ölçümler gibi her türlü jeolojik verinin "Görüntü işleme ve Analizi", "CBS", "Uzaktan Algllama”, "Bulanık Mantık" ve "Yapay Zekâ" gibi bilgi işlem uygulamalarıyla adaptasyonu olarak düşünülebilir.

Son 15 yllda Eğirdir'de yürütülen mermercilik faaliyetleri ekonomik olarak başarılı sonuçlar getirmiştir. $\mathrm{Bu}$ faaliyetlerin gerçekleştirildiği kireçtaşları çoğunlukla bej renktedir. $\mathrm{Bu}$ nedenle benzer bej mostralarının bulunması ekonomik olarak büyük önem taşımaktadır. Bu kapsamda bölgede verimli olarak nitelendirilebilecek 16 adet ocakta; faaliyet gerçekleşmeden önceki uydu görüntülerinin analizleri, jeomorfolojik özelliklerime ait veriler ve saha gözlemleri bilgisayar ortamında değerlendirilmiștir. Elde edilen ve oluşturulan dijital veriler temel alınarak benzer özellik gösteren lokasyonların bulunması gerçekleştirilmiştir. Tüm 
bunların sonucunda tespit edilen lokasyonlarda mermercilik yapılıp yapılmadı̆̆ı, yapıldıysa sonuçlarının ne olduğu gibi karşılaştırmalar ile bu çalışmada uygulanan yöntemlerin başarısı araştırılmıştır. Çalışma kapsamında verilerin sayısallaştırması, ihtiyaç duyulan her türlü jeolojik veriye uygulanmış ve sonuçları bilgisayar ortamında görsel yorumlama, sınıflama ve analiz (çözümleme) yöntemleri ile değerlendirilmiştir.

Çalışma konusu ile ilgili benzer bir araştırmaya rastlanılmamıştır. Ancak bölge jeolojisi ile ilgili yeterli bilimsel envanter bulunmaktadır. Yalçınkaya vd (1986), Dumont ve Kerey (1975), Gutnic vd. (1979), Akbulut (1980), Koçyiğit (1983), Karaman vd. (1989), Görmüş ve Özkul (1995), Şenel (1997), Irlayıcı (1998),), Uysal (2004), Uysal (2011), Caran (2014), Uysal ve Caran (2014) gibi çalışmalar stratigrafi, tektonik, mermercilik ve çevre jeolojisi gibi bu araştırmanın konusu ile ilişskili bulgular içermektedir. Kaya (1999), Buzlu (2001),Kızıltaş (2005), Sarı (2005), Doğan vd. (2007), Uysal vd. (2008), Yakan (2009), Dereli vd.(2010), Efe (2013), Kayadibi (2013), Hepdeniz (2014), Francioni vd. (2015), Tekin vd. (2016), Demir (2017) gibi araștırmacılar ise sayısal jeoloji ile ilișkilendirilebilecek bilgisayar yazılımlarının ağırlıklı olarak kullanıldığı uzaktan algllama ve CBS temelli çalışmalar gerçekleştirmişlerdir.

İnceleme alanında Mesozoyik zamanına kadar uzanan yaşlarda allokton ve otokton kaya birimleri yer alır. Otokton birimler Beydağları otoktonuna ait değisşik kayaçlardan oluşur. Allokton birimler ise Antalya naplarına ait farklı kökenli kayaçlar içeren istif sunar. Ocak alanlarında Otokton birimlerden Triyas-Jura yaşlı Ispartaçay formasyonu (TrJı), Üst Kretase yaşlı Beydağları Karbonatları (UKrs) ve Kuvaternergünümüz yaşlı Güncel çökellerdir (Qal). Allokton birimler ise Triyas-Jura oluşum ve yerleşim yaşına sahip Tekedağ formasyonu (TrJt) ve Triyas oluşum ve Üst Kretase yerleşim yaşına sahip Isparta Ofiyolitik Karmaşığıdır (Tı) (Şekil 1).

İncelemeye konu olan bej kireçtaşları (Ottoman) Tekedağ fm. ait kireçtaşlarıdır. Kalın katmanlı, açık bej renkli, kalın tabakalı, masif görünümlüdür. Taze yüzeyleri krem, bazen de açık gri renklidir. Ispartaçay formasyonu ile tektonik bir dokanak oluşturmaktadır (Şekil 2).

\section{Materyal ve Metot}

Çalışmada sırasıyla; literatür araştırma, veri temini, görüntü ișleme ve analiz, dijital veri aktarımı ve hesaplamalar, saha kontrolü ve yorumlama aşamalarından geçilmiștir (Şekil 3). Ücretsiz temin edilen Landsat uydu görüntüleri (Earthexplorer), MTA ruhsat sorguları (MTA), ve 1/25.000 ölçekli topoğrafik haritalar sayısal veri üretimi için kullanılmıștır.

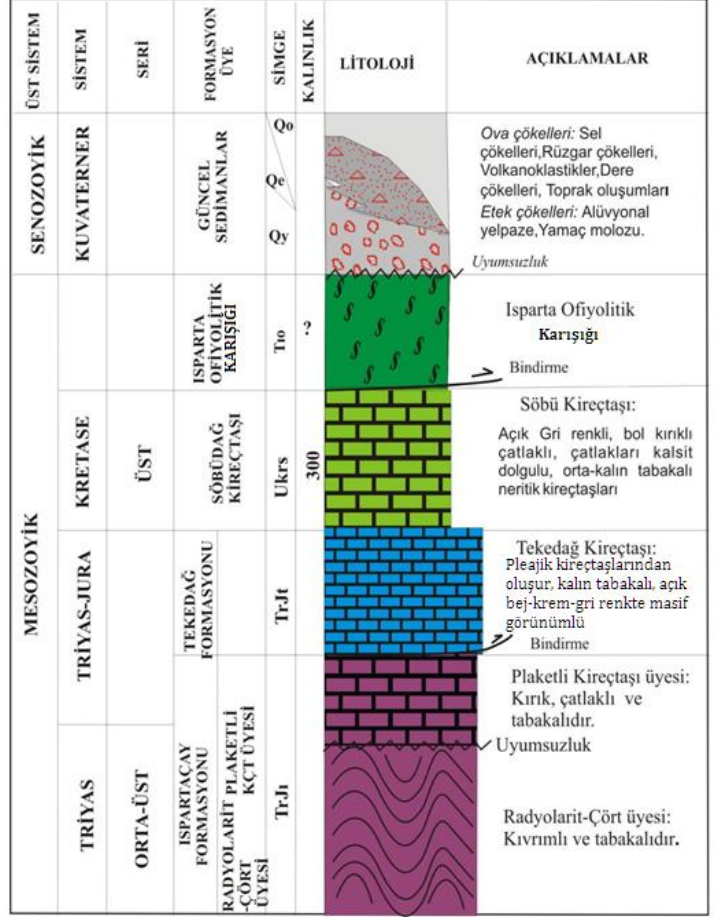

Şekil 1. Genelleștirilmiş tektono-statigrafik sütun kesit (ölçeksiz) (Poisson 1967, Yalçınkaya vd. 1986, Karaman vd. 1989, Şenel 1997)

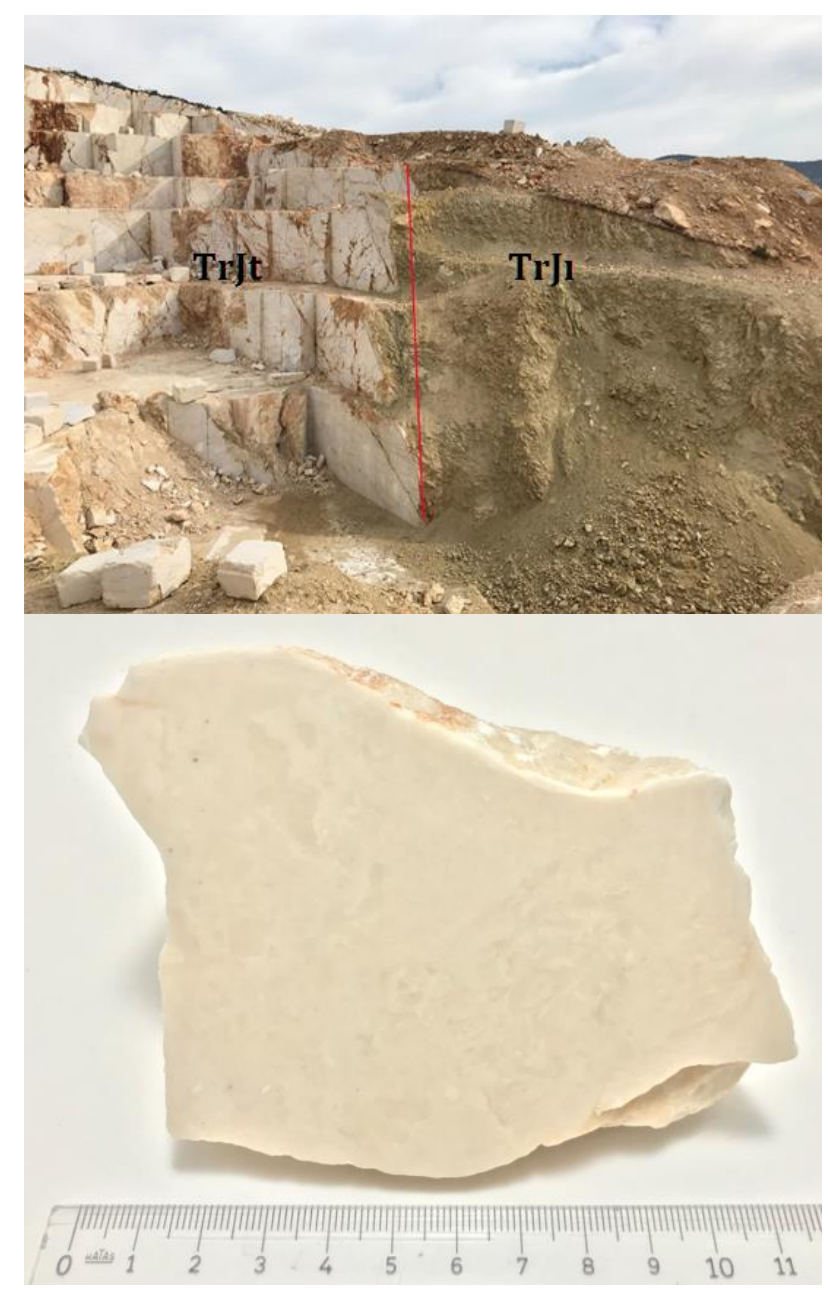

Şekil 2. Tekedağ fm. (TrJt) ile Isparta çay fm.(TrJı) arasındaki tektonik dokanak (Besmar Ocağı) ve Bej kireçtaşlarına ait el numunesi 
İnceleme koordinatları UTM projeksiyonu-ED50 datum-36. Kuzey bölgedeki; 1. 284995D,4204991K, 2. $329898 \mathrm{D}, 4204881 \mathrm{~K}, 3$. 330040D,4175048K, 4. 285043D,4175119K noktaları arasında yer alan yaklaşı $1340 \mathrm{~km}^{2}$ 'lik alanı kapsayan Landsat uydu görüntüleri kullanılarak gerçekleştirilmiştir (Şekil 4). 2005 yılı haziran ayı ve 2017 yll temmuz ayı görüntüleri bitki, bulut, kar gibi özelliklerden dolayı seçilmiştir. Uydu görüntülerinde görüntü zenginleştirme işlemleri yapılmıştır (Şekil 4). Jeolojik çalışmalar için kızılötesi tayf bantlarının yer aldığı kompozit görüntüler daha kullanışlı olmaktadır (Jensen, 2005). Çizelge 1'de kullanılan kombinasyonların tamamı denenmiş ve LS5 543 ve LS8 654 kombinasyonları sinıflamalardaki başarı oranından dolayı tercih edilmiştir.

Sahadaki bej kireçtaşı kütleleri ve diğer litolojilerin tespiti için uydu görüntülerinde görsel yorumlama, eğitimli ve eğitimsiz sinıflama işlemleri gerçekleştirilmiştir (Şekil 3-6).

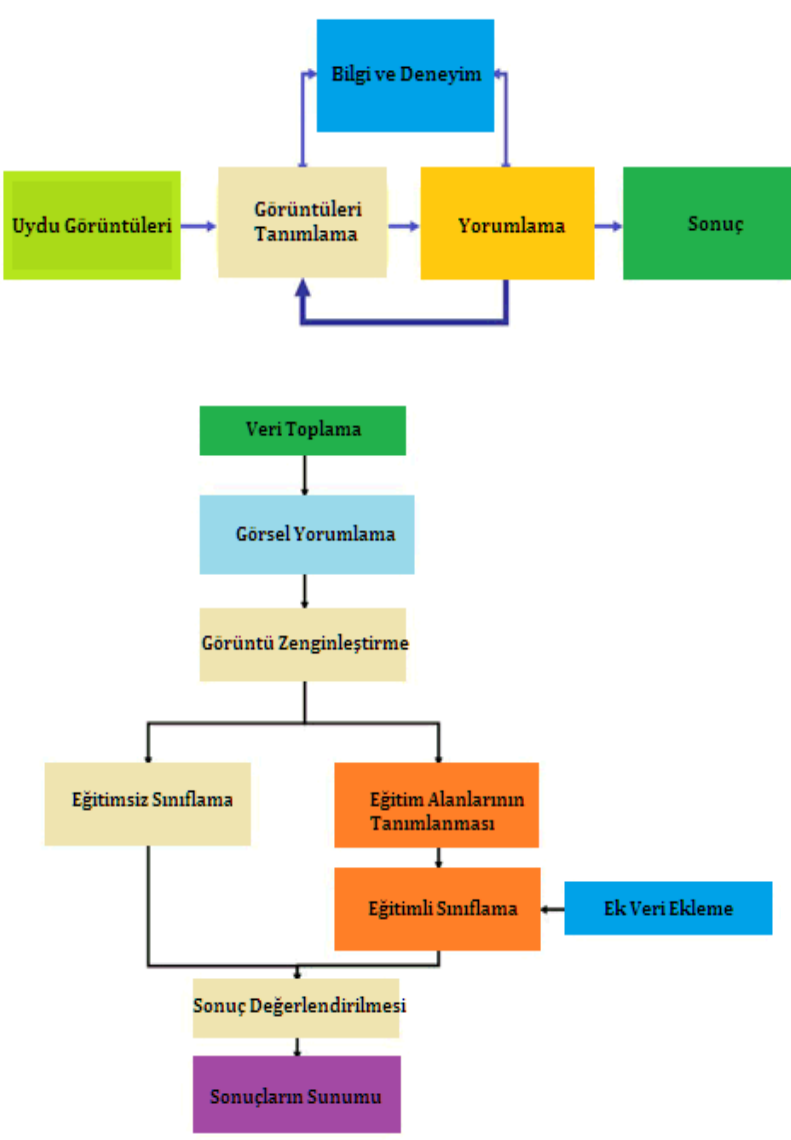

Şekil 3. Görsel yorumlama ve sınıflandırma süreci

Bej mostralarının morfolojik özelliklerini diğer litolojilerden ayırabilmek için tüm çalışma alanına ait Sayısal yükseklik modeli (SYM), yamaç eğim yönü (bakı) haritası, yamaç eğim miktarı haritası, drenaj haritası ve çizgisellik haritası oluşturulmuştur.
Çizelge 1. Landsat 8 ile yaygın kullanılan KYM (RGB) kombinasyonlarının uygulama alanları (Esri)

\begin{tabular}{|l|l|l}
\hline Kullanım & $\begin{array}{l}\text { KYM } \\
\text { Kombinasyonu } \\
\text { Landsat 5 }\end{array}$ & $\begin{array}{l}\text { KYM } \\
\text { Kombinasyonu } \\
\text { Landsat 8 }\end{array}$ \\
\hline Doğal renkler & 321 & 432 \\
\hline Bitki Değişimi*** & 521 & 632 \\
\hline Yalancı renk (Șehir) & 753 & 764 \\
\hline Renkli kızılötesi (bitki) & 432 & 543 \\
\hline Tarım alanı & 541 & 652 \\
\hline Atmosferik girişim & 754 & 765 \\
\hline Sağlıklı bitki gelişimi & 451 & 562 \\
\hline Yalancı renk (bitki) & 471 & 571 \\
\hline Su-Kara & 453 & 564 \\
\hline Atmosfersiz doğal & 742 & 753 \\
\hline Kısadalga kızı̈ötesi $* * *$ & 743 & 754 \\
\hline Bitki analizi & 543 & 654
\end{tabular}

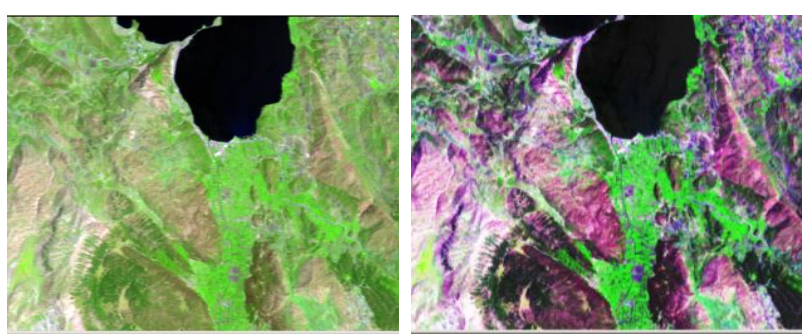

Şekil 4. Landsat5 uydu görüntüsünde 5-4-3 kombinasyonu ham ve ișlenmiş görüntüler

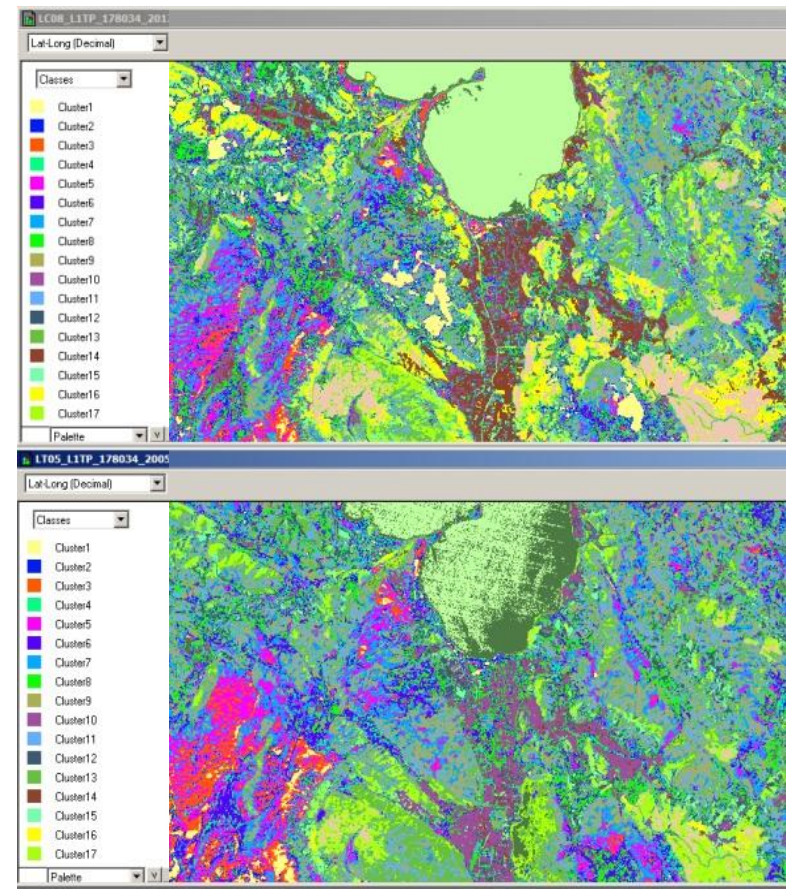

Şekil 5. Landsat 8 uydu görüntüsü 6-5-4 ve Landsat-5 uydu görüntüsünde 5-4-3 kombinasyonu sınıflandırılmış görüntüler

Bej kireçtaşlarında açılmış ocak alanları seçilerek herbir ocak alanındaki morfolojik veriler sayısal olarak elde edilmiştir (Şekil 8-9). 


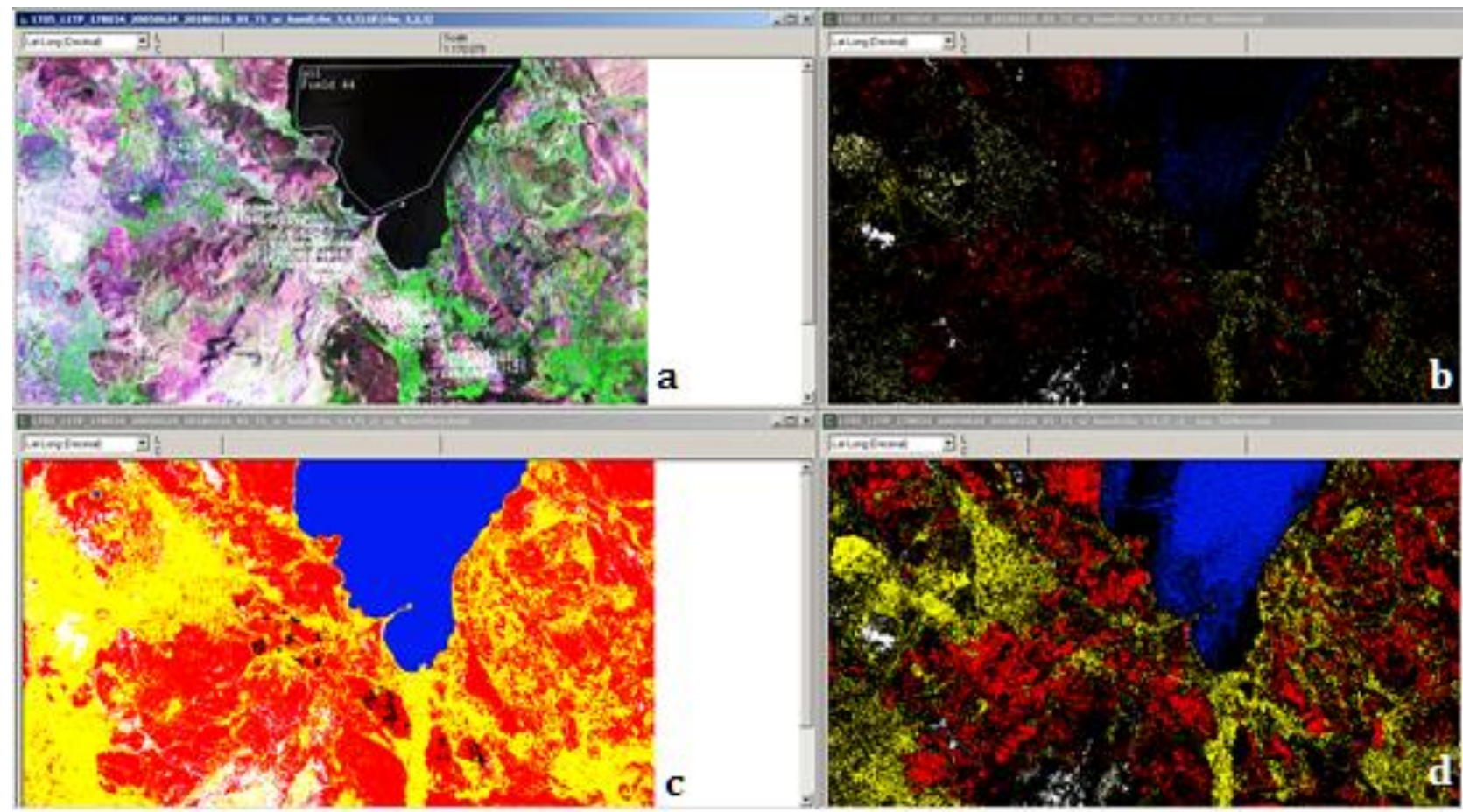

Şekil 6. Eğitimli sınıflama işlemleri (Multispec) - a) Test alanları b) Eşik değer \%90 c) Eşik değer \%0, d) Eşik değer \%50

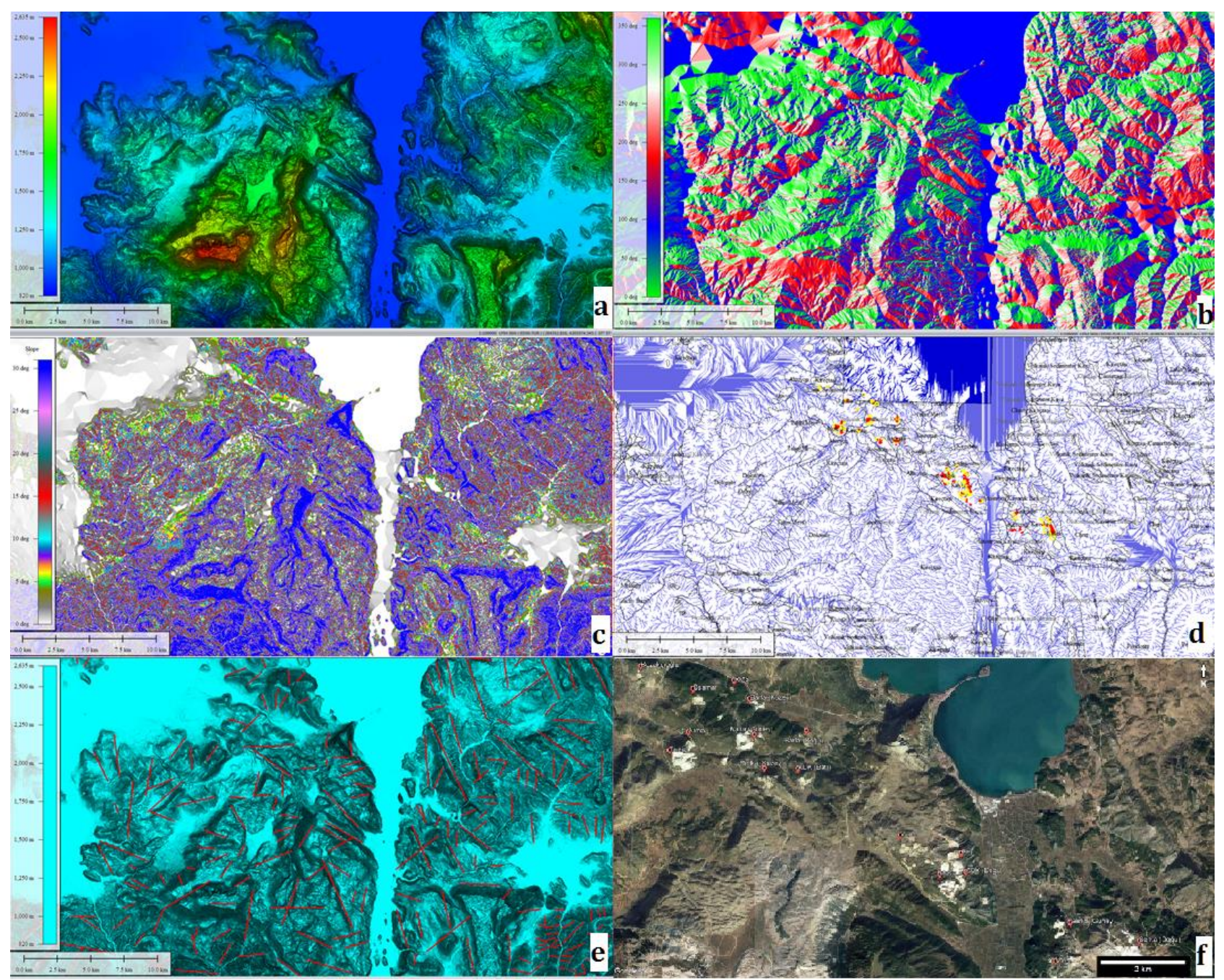

Şekil 7. Morfolojik veriler a) Yükseklik haritası b) Yamaç eğim yönü haritası c) Yamaç eğim miktarı haritası d) Drenaj haritası e) Çizgisellik haritası f) Uydu görüntüsü 


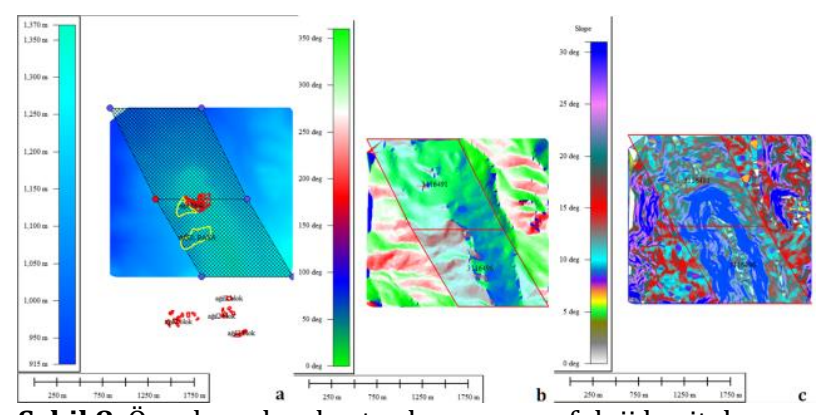

Şekil 8. Örnek ocak ruhsat sahasının morfoloji haritaları a) Yükseklik b) Bakı- Yamaç eğim yönü c) Yamaç eğim miktarı

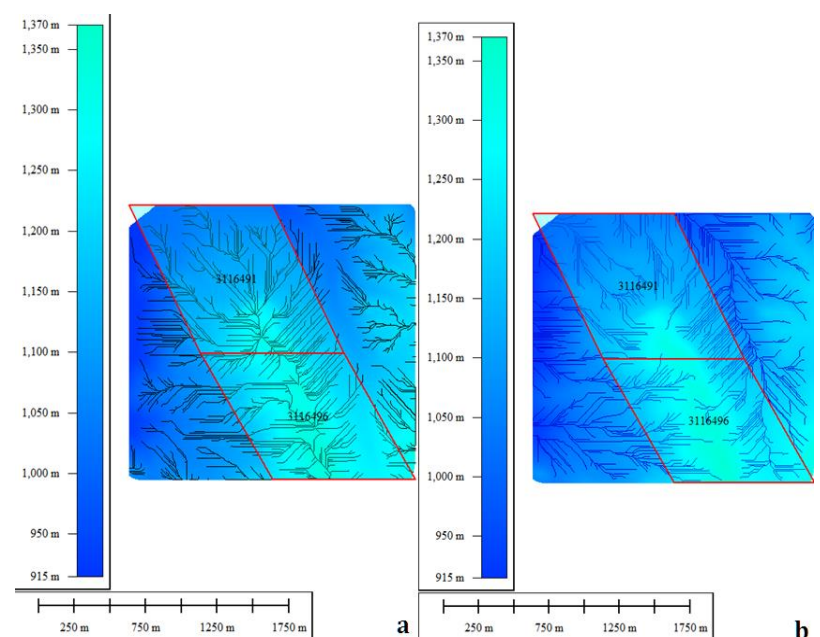

Şekil 9. Örnek ocak ruhsat sahasının morfoloji haritaları a) Drenaj haritası b) Sirt haritası

\section{Bulgular}

$\mathrm{Bu}$ çalışmada araştırma yapılan sahaya ait jeoloji haritası dikkate alınarak eğitimsiz sınıflamada 20 sınıf oluşturulmasına karar verilmiştir. Farklı sınıf sayıları da denenmiş ve 20 sınıfın en uygunu olduğu görülmüştür. Ocak açllmadan önceki görüntü olduğu için Landsat 5 uydu görüntülerinden tayf değerleri analiz edilerek jeolojik yorumlama için en uygun olan bant kombinasyonları değerlendirilmiş ve görüntüler eğitimsiz olarak 20 sınıfa ayrılmıștır. Belirlenen sınıf karşılıklarına ait sayısal renk değerleri yorumlanmıştır ve her bir birimin yayılım alanları ortaya konmuştur (Çizelge 2, Şekil 10).

Mevcut jeolojik haritadaki litolojiler dikkate alındığında sınıfların karşılık geldiği litolojiler şöyledir: Sahadaki tüm kireçtaşları 5-7-9. sınıf içerisinde yoğunluktadır. Dolomitler 1-3-4-6. sınıflarda gözlenir. Kumtaşı, silttaşı, kiltaşı içerikli birimler 7-9-18 sınıflarda yer alır. Kongolomeralar 48-9, Şeyl içeren birimler 8-10-12. sinıflarda yer alır. Radyolarit, çört, kalsitürbidit, mikrit, çörtlü mikrit içerikli birimler yoğun olarak sınıf 8-16-18'de gözlenmektedir. Harzburjit, bantlı harzburjit ve serpantin içerikli birimler 7-8-13-18. sinıflarda gözlenmektedir. Ofiyolit melanj içerikli birimler sınıf 2-4-8'de gözlenir. Bitkili kumtaşı şeyl, çört, halobialı kireçtaşı içerikli birimler sınıf 2-7-8-9'da gözlenir.
Yamaç molozu ve birikinti konileri sınıf 3-5-7'de gözlenir. Alüvyon sınıf 1-2-3-9-15'de gözlenir. Göl ise 20. Sınıf olarak ayırt edilebilmektedir.

Aranan özelliklerdeki bej kireçtaşları diğer kireçtaşları gibi 5-7-9. Sınıflarda yer alır. Bununla beraber günümüzde ocak açılmış sahalarda 6-7-9-10$11-13$ ve 15 . sinıflar gözlenir.

Çizelge 2. LS5- 543 eğitimsiz sinıflama sonuçları

\begin{tabular}{|l|l|l|l|}
\hline Sinıflar & Örnek Saylları & Yüzde(\%) & Alan (Hektar) \\
\hline Sinıf1 & 35.796 & 2.39 & 3.222 \\
\hline Sinıf2 & 49.229 & 3.28 & 4.431 \\
\hline Sinıf3 & 53.122 & 3.54 & 4.781 \\
\hline Sinıf4 & 73.770 & 4.92 & 6.639 \\
\hline Sinıf5 & 75.656 & 5.04 & 6.809 \\
\hline Sinıf6 & 91.548 & 6.10 & 8.239 \\
\hline Sinıf7 & 102.336 & 6.82 & 9.210 \\
\hline Sinıf8 & 111.372 & 7.42 & 10.023 \\
\hline Sinıf9 & 124.633 & 8.31 & 11.217 \\
\hline Sinıf10 & 53.565 & 3.57 & 4.821 \\
\hline Sinıf11 & 115.750 & 7.72 & 10.418 \\
\hline Sinıf12 & 103.052 & 6.87 & 9.275 \\
\hline Sinıf13 & 80.679 & 5.38 & 7.261 \\
\hline Sinıf14 & 45.420 & 3.03 & 4.088 \\
\hline Sinıf15 & 75.123 & 5.01 & 6.761 \\
\hline Sinıf16 & 50.744 & 3.38 & 4.567 \\
\hline Sinıf17 & 57.873 & 3.86 & 5.209 \\
\hline Sinıf18 & 45.842 & 3.06 & 4.126 \\
\hline Sinıf19 & 1.569 & 0.10 & 141 \\
\hline Sinıf20 & 152.921 & 10.19 & 13.763 \\
\hline Toplam & 1.500 .000 & 100 & 135.000 \\
\hline
\end{tabular}

Ocak alanlarının yerleri Landsat 8 ve Google Earth görüntülerinde sayısallaştırılmıştır. Görsel olarak kolay ayırt edilebilen göl ve tarım alanları da kullanılarak test alanları oluşturulmuştur. Ocak, göl ve tarım alanları temel alınarak eğitimli sınıflama yapılmıştır (Şekil 11). Multispec yazılımında eşik değer \%90 olarak seçildiğinde; bej kireçtaşı görüntünün \%1.831'lik kısmını kapsamaktadır. Geomatica yazılımında ise eşik değer 1 olarak seçildiğinde bu oran \%1.14 olarak bulunmuştur. Her iki uygulamada yapılan eğitimli sınıflamalar karşılaştırıldığında, eşik değerin düşük tutulması sonucu daha güvenilir kılmaktadır. Bej kireçtaşlarının sahadaki yayılımları test alanlarının belirlenmesindeki hassasiyete bağlı olarak \%3 ile \%1 arasında değişiklik göstermektedir. 


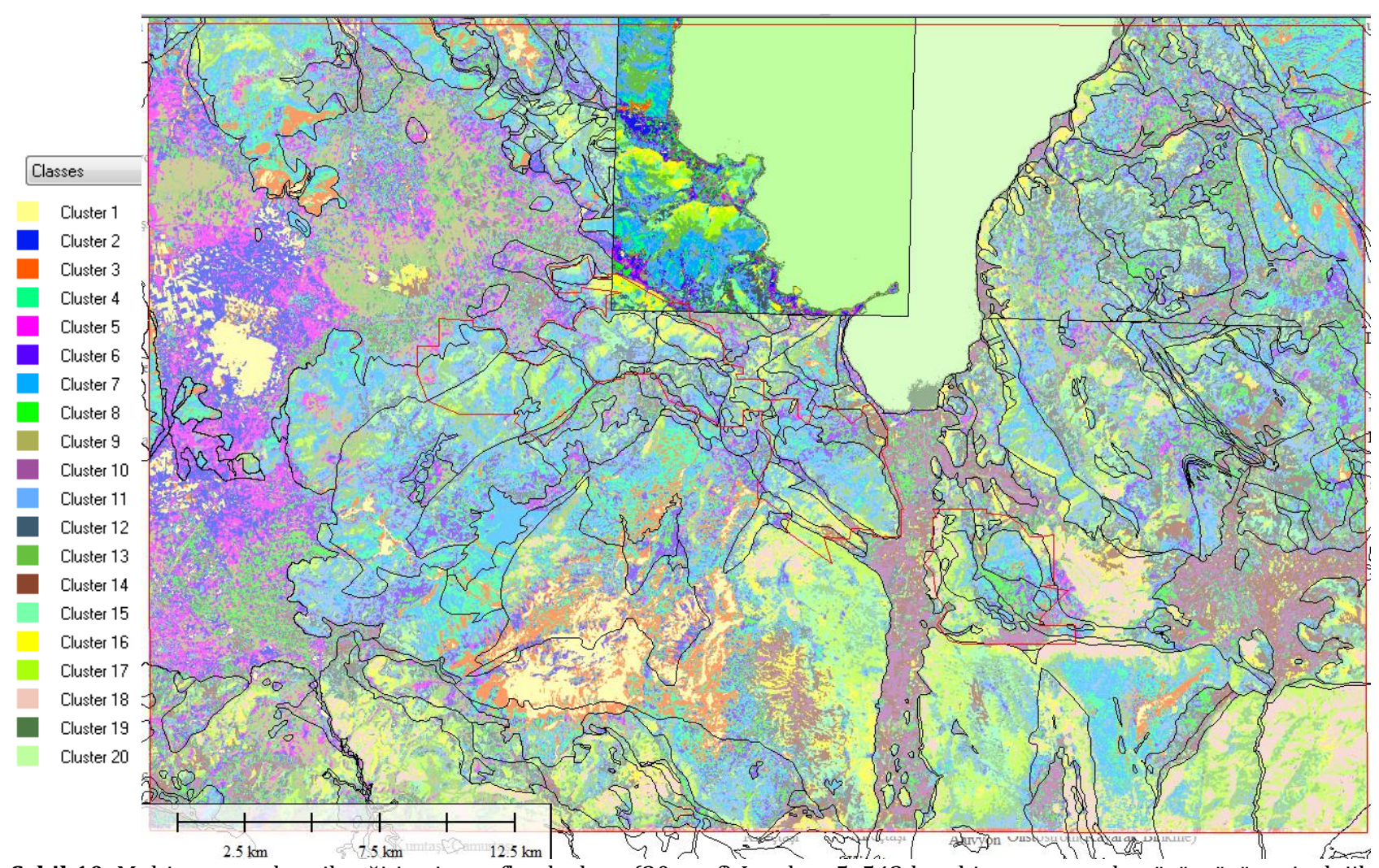

Şekil 10. Multispec yazılımı ile eğitimsiz sınıflandırılmış (20 sınıf) Landsat-5, 543 kombinasyonu uydu görüntüsü ve jeolojik haritadan alınan litoloji sınırları üzerine çakıștırılması. Sınıflama sonuçları ile mevcut litoloji sınırları büyük oranda uyum göstermektedir

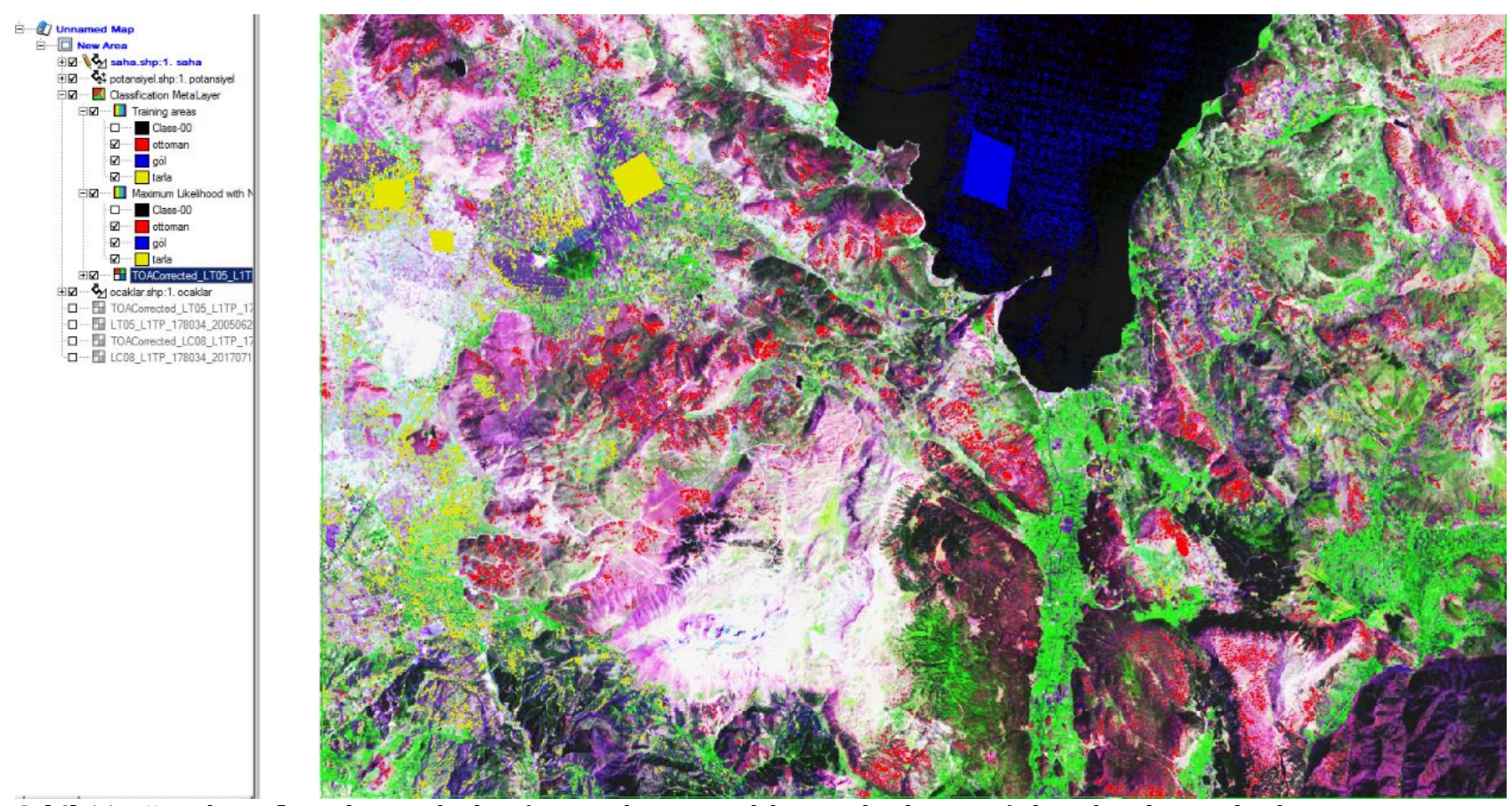

Şekil 11. Eğitimli sınıflamada test alanları (sarı: tarla, mavi:göl, kırmızı:bej kireçtaşı) ile sadece benzer bej kireçtaşı lokasyonlarının belirlenmesi 
Mevcut ocak yerleri eğitimli sınıflama doğruluğunu test etmek ve bej kireçtaşlarının sayısal renk değerlerinin bulunması için kullanılmıștır. Buna göre, kullanılan LS5 görüntü kombinasyonunda bej kireçtaşlarının sayısal renk değerleri ortalama 106,44 ile 129,69 arasında değişmektedir (Çizelge 3).

Çizelge 3. Ocak alanları LS5- 543 sayısal renk değerleri

\begin{tabular}{|c|c|c|c|}
\hline & Renk değe & eri & \\
\hline Ocak İsimleri & Minimum & Maximum & Ortalama \\
\hline $\begin{array}{l}\text { Kozakçıoğlu } \\
\text { ocağı }\end{array}$ & 137 & 178 & 161 \\
\hline Besmar ocağ & 87 & 151 & 109 \\
\hline RMS ocağı & 85 & 119 & 105 \\
\hline Arma ocağı & 98 & 148 & 126 \\
\hline Tuaiçi ocağl & 119 & 179 & 142 \\
\hline Barla (k-g) ocağ & 82 & 179 & 130 \\
\hline Serka(k) ocağ & 106 & 141 & 120 \\
\hline ADK (batı) ocağı & 115 & 165 & 137 \\
\hline Barla (d) ocağ & 99 & 184 & 142 \\
\hline Yüce ocağ & 115 & 178 & 150 \\
\hline Bej ocağı & 100 & 181 & 137 \\
\hline ADK (d) ocağl & 99 & 180 & 135 \\
\hline Masa ocağı & 139 & 187 & 169 \\
\hline Serka (g) ocağ & 92 & 144 & 11 \\
\hline UYK ocağı & 118 & 168 & 144 \\
\hline Seka (d) ocağı & 112 & 213 & 157 \\
\hline $\begin{array}{l}\text { Ortalama } \\
\text { değerler }\end{array}$ & 106,44 & 168,44 & 129,69 \\
\hline
\end{tabular}

İnceleme alanının tamamında morfolojik bulgular şöyledir; yükseklik 820-2615 m. arasında değișmektedir. Yamaç eğim yönleri ağırlıklı olarak 200-250 derece ve 300-350 derece aralığında değişmektedir. Yamaç eğim miktarı haritasında yamaçlara ait eğim miktarı ise ağırlıklı olarak 10 derece ile 30 derece arasında değişir (Şekil 7).

Ocak alanlarındaki morfolojik veriler incelendiğinde; yükseklik ortalaması 1257 metre olarak bulunmuştur. Yamaç eğim miktarları ortalaması \% 16,25 , yamaç eğim yönü ortalaması ise K169 derece olarak bulunmuştur (Çizelge 4).

$\mathrm{Bu}$ kriterleri sağlayan bölgeler eğitimli sınıflama sonuçları ile birlikte değerlendirildiğinde büyük oranda benzerlik sundukları görülmüștür. Bu da bej kireçtaşı içeren mostraların çoğunlukla 1100-1500 m. arasında, güneye ve batıya eğimli, orta ve-yer yer dik eğimlere sahip morfolojilerde aranması gerektiğini ortaya koymaktadır.

İnceleme alanında konumları bilinen bej kireçtaşı kütlelerinde mevcut vadi sistemlerini belirlemek için SYM kullanılarak drenaj ağı modeli olușturulmuștur (Şekil 7). Bu veri her ocak lokasyonu için değerlendirildiğinde bej kireçtaşlarında kaba dendritik ve yarı paralel drenaj ağlarının hakim olduğu belirlenmiştir.

Çizelge 4. Tüm ocak sahalarına ait morfolojik veriler

\begin{tabular}{|l|l|l|l|l|}
\hline Ocak Adları & Rakım & $\begin{array}{l}\text { Yamaç } \\
\text { eğim } \\
\text { miktarı } \\
(\%)\end{array}$ & $\begin{array}{l}\text { Yamaç } \\
\text { eğim } \\
\text { yön }\left(^{\circ}\right.\end{array}$ & $\begin{array}{l}\text { Drenaj } \\
\text { Tipi }\end{array}$ \\
\hline $\begin{array}{l}\text { Kozakçığlu } \\
\text { ocağı }\end{array}$ & 1075 & 15 & 15 & P-D \\
\hline Besmar ocağı & 1200 & 15 & 200 & P \\
\hline RMS ocağı & 1075 & 10 & 175 & P-D \\
\hline Arma ocağı & 1300 & 20 & 75 & P-D \\
\hline Tuaiçi & 1300 & 12,5 & 200 & P-D \\
\hline Barla (K-G) ocağı & 1075 & 12,5 & 275 & P \\
\hline Serka (K) ocağı & 1375 & 25 & 200 & P \\
\hline ADK (batı) ocağı & 1400 & 10 & 200 & P \\
\hline Barla (D) ocağı & 1125 & 15 & 150 & P-D \\
\hline Yüce ocağı & 1450 & 15 & 110 & P-D \\
\hline Bej ocağı & 1350 & 15 & 125 & P-D \\
\hline ADK (D) ocağı & 1275 & 15 & 125 & P-D \\
\hline Masa ocağı & 1350 & 17,5 & 100 & P-D \\
\hline Serka(G)ocağı & 1225 & 20 & 250 & P \\
\hline UYK ocağı & 1225 & 22,5 & 225 & P \\
\hline Serka (D) ocağı & 1325 & 20 & 275 & P \\
\hline $\begin{array}{l}\text { Ortalama } \\
\text { değerler }\end{array}$ & 1257,8 & 16,25 & 168,75 & P/P-D \\
\hline
\end{tabular}

Landsat görüntüleri ile inceleme alanındaki litolojilerde bitki yoğunluğuda tespit edilmiștir. Normalleștirilmiş Bitki Örtüsü Fark İndeksi NDVI=B4-B4/B4+B3 (B4= Yakın Kızılötesi B3: Kırmızı) (Rouse vd., 1973) kullanılarak inceleme alanında ve ocak alanlarında meydana gelen bitki değișimi incelenmiștir ve bitki yoğunluğu haritası hazırlanmıştır (Şekil 12). Bu harita jeolojik haritayla birlikte değerlendirilerek hangi birimin ne yoğunlukta bitki örtüsüne sahip olduğu belirlenmiş ve her bir ocak yerinin ve sahada yayılım gösteren birimlerin sayısal jeolojik bitki yoğunluğu değeri ortaya konmuştur. Landsat 8 ve 5 yaz görüntülerinden NDVI (normalize fark bitki indisi) ile eğitimsiz sınıflama ile 20 sınıfa ayrılmıştır. Sonuçta elde edilen sinıflardan 1-3 çok yoğun, 4-7 yoğun, 8-10 seyrek, 11-12 çok seyrek, 12-20 bitkisiz alanları temsil ettiği görülmüștür. 

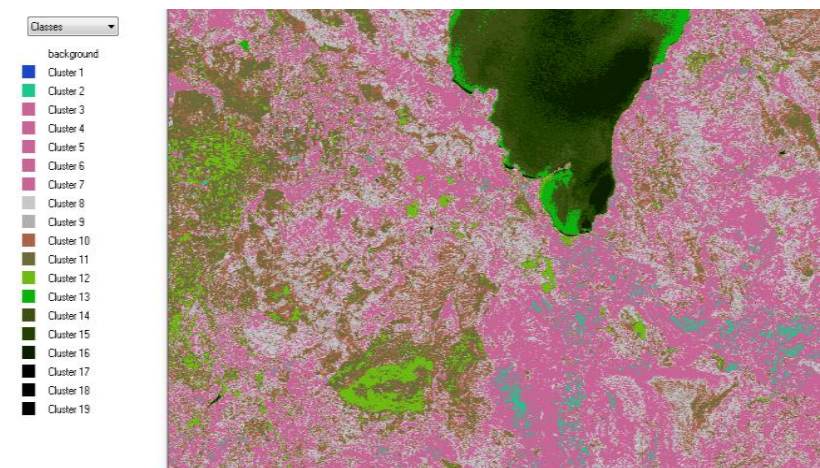

Şekil 12. Çalışma alanına ait 2017 yılı Temmuz ayı NDVI (normalize fark bitki indisi)20 sınıf eğitimsiz sınıflama sonucu

Eğitimli sınıflama, morfolojik veriler ve bitki yayılım özellikleri birleștirilerek değerlendirildiğinde potansiyel bej kireçtaşı alanları ortaya çıkmıştır (Şekil 13). Bu alanlardan üzerinde ocak açılmamış 7 bölge test amaçlı seçilmiştir (Şekil 14). Buralarda gerçekleştirilen arazi gözlemlerinde 6 tanesinde bej kireçtaşı mostralarının bulunduğu görülmüștür (Şekil $15)$.

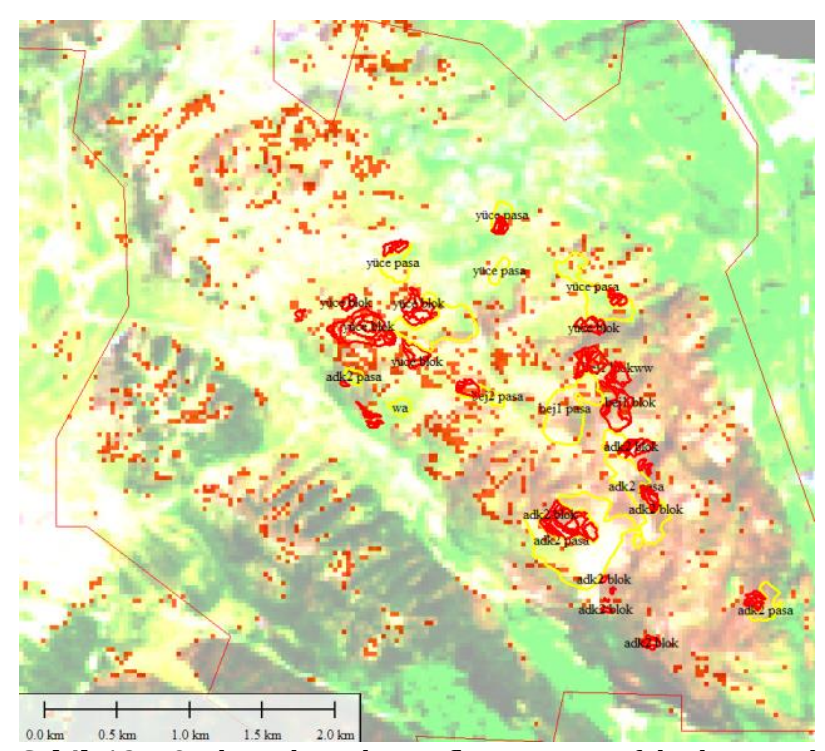

Şekil 13. Ocak yerlerinde sinıflama ve morfolojik sayısal değerlerin sonuçlarının birleștirilmesi

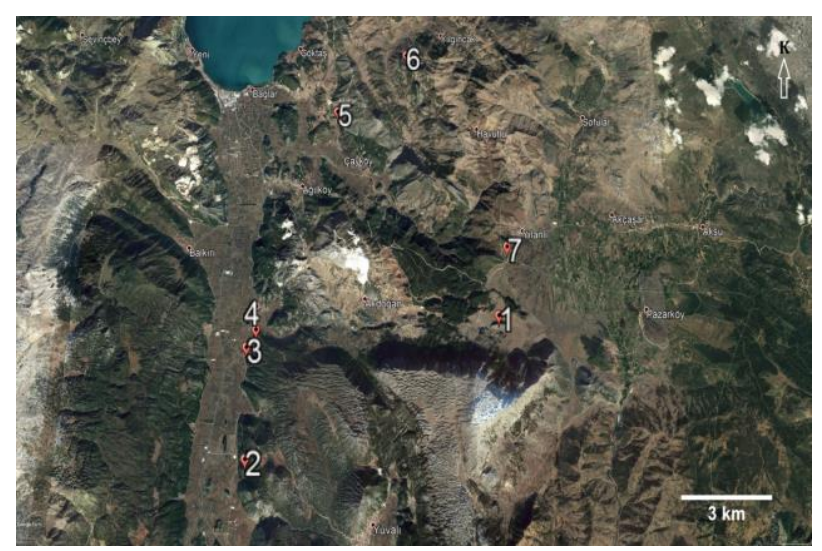

Şekil 14. Tüm potansiyel sahalar içerisinden seçilip arazi çalışması yapılan lokasyonlar
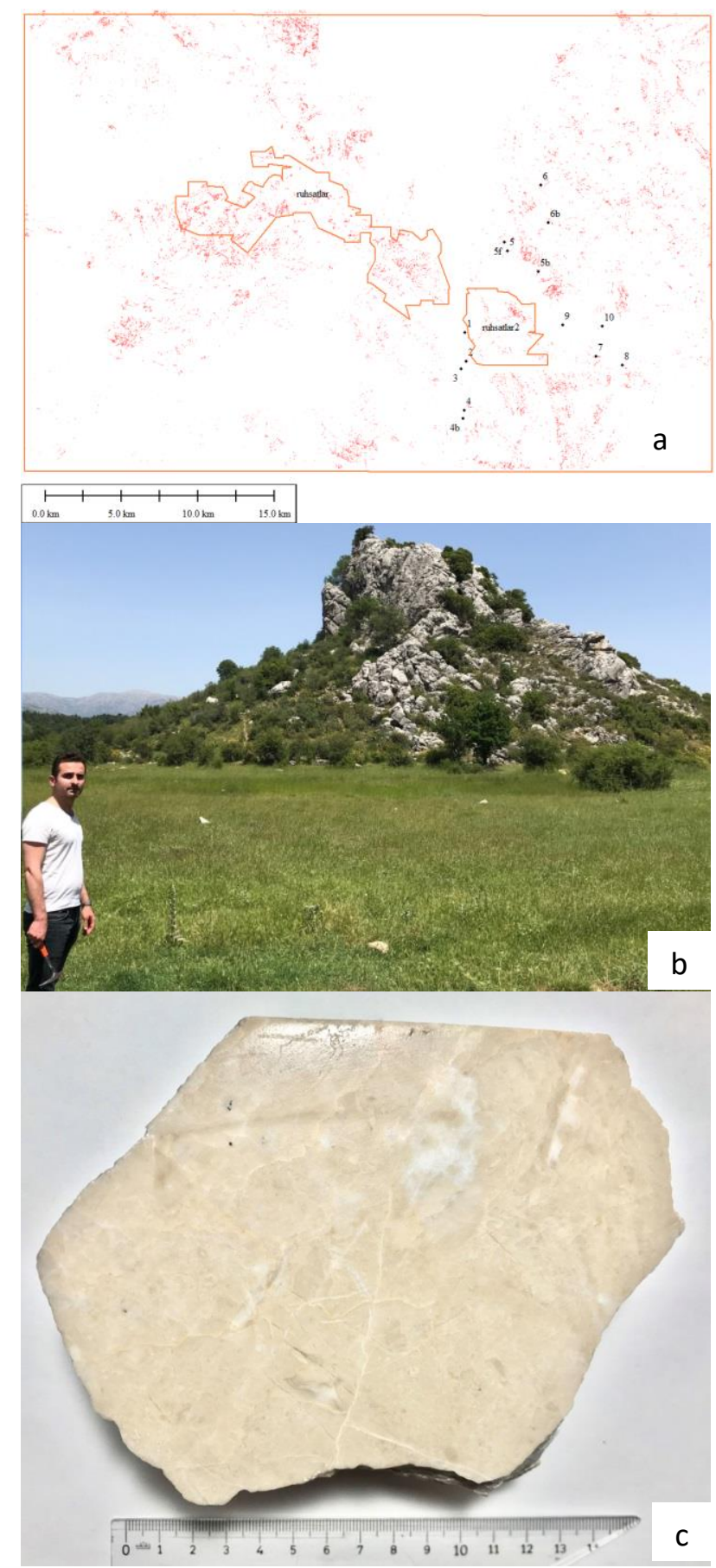

Șekil 15. a)Kırmızı noktalar potansiyel bej kçt. lokasyonları, dörtgen alanlar işletme ve arama ruhsatı olan sahalar. b) 1. Lokasyon mostra görünümü c) 1. Lokasyona ait kesilip parlatılmış numune

\section{Tartışma ve Sonuç}

Çalışmada cevap aranan soru şudur;

Sayısal jeolojik veriler kullanarak Eğirdir bej mermer ocaklarındaki kireçtaşlarına benzer mostraların tespiti mümkün müdür?

Uydu görüntülerinde gerçekleştirilen ayrıntılı görüntü analiz sonuçları beraberinde morfolojik veriler ile elde edilen sayısal veriler değerlendirildiğinde benzer bej kireçtaşı 
mostralarının yani potansiyel mermer sahalarının tespiti mümkündür (Şekil 14).

Çalıșma kapsamında ortaya konan sayısal jeolojik özellikler şunlardır;

20 sınıf üzerinden yapılan eğitimsiz sınıflama sonuçları eğitimli sınıflamada kullanılan ocak lokasyonları ve jeolojik harita ile eșleștirilerek yorumlandığında bej kireçtaşı mostraları içeren sınıfların belirlenebildiği ortaya konmuștur.

Eğitimsiz sınıflama sonuçlarına göre 135 hektarlık alan içerisinde yaklaşık 27 hektar alan bej kireçtaşı içerme potansiyelindedir. $\mathrm{Bu}$ sonuç eğitimsiz sınıflamanın çalışmanın amacına uygun olmadığı sonucunu düşündürmektedir.

Eğitimli sınıflama karşılaştırmalı olarak iki farklı yazılım kullanılarak yapılmıştır. Buna göre; eşik değerin düşük tutulması sonucu daha güvenilir kılmaktadır. Bej kireçtaşlarının sahadaki yayılımları test alanlarının belirlenmesindeki hassasiyete bağlı olarak \%3 ile \%1 arasında değișiklik göstermektedir. Sınıflama güvenilirliği \%60'ın üzerindedir. Sınıflama sonuçları görsel olarak yorumlandığında ise yüksek oranda doğru olduğu ve çalışmanın amacına daha uygun olduğu görülmüştür.

Landsat 5 görüntülerinde 543 Landsat 8 görüntülerinde ise 654 kombinasyonlarının bej kireçtaşı mostralarının belirlenmesi için en uygun kombinasyonlardan biri olduğu sonucuna varılmıștır.

Morfoloji verilerine göre bej kireçtaşı içeren mostraların çoğunlukla 1100-1500 m ler arasında, güneye ve batıya eğimli, orta ve-yer yer dik eğimlere sahip morfolojilerde aranması gerektiğini ortaya koymaktadır.

SYM analizi ve görsel yorumlama sonuçlarına göre inceleme alanında bulunan bej kireçtaşlarında kaba dendritik ve yarı paralel drenaj ağlarının hakim olduğu belirlenmiştir.

Bej kireçtaşı mostralarına ait eğitimli sınıflama sonuçları ve mevcut ocak yerlerinin bulunduğu alanlarla birlikte incelendiğinde bej kireçtaşı mostralarının çoğunlukla KB yönlü çizgiselliklerin sınırlandırdığı yükseltilerde olduğu görülür. Ocak alanlarındaki eklemler ile saha genelinde görülen çizgisellikler yaklaşık olarak birbiri ile dik konumludurlar.

Ortalama renk değerleri dikkate alındığında bej kireç taşlarının yayılım gösterdiği alanlarda NDVI renk değerinin düşük olduğu, dolayısı ile bitki sıklığının az olduğu görülmüştür.

Sonuç olarak sayısal jeoloji çalışmalarının doğaltaş aramalarında kullanılabilirliği bu çalışma ile ortaya konmuştur.

\section{Kaynakça}

[1] Akbulut, A., 1980. Eğirdir Gölü Güneyinde Çandır (Sütçüler, Isparta) Yöresindeki Batı Torosların Jeolojisi. Türkiye Jeoloji Kurumu Bülteni, 23, 1-9.

[2] Buzlu, H.B., 2001. Bayat (Atabey - Isparta) Kireçtaşlarının Mermer Olarak Kullanılabilirliği ve Ekonomik Potansiyeli, Türkiye III. Mermer Sempozyumu (Mersem '2001), 3 - 5 Mayıs, İzmir, 417-430.

[3] Caran, Ş., 2014. Isparta Mermer Potansiyeline Bir Bakıș. Ulusal Mermer ve Taş Ocakları Onarım Teknikleri Sempozyumu, 18-20 Eylül, Isparta, 242-254.

[4] Demir, E., 2017. Bir Mermer Ocağından Çıkartılan Blok Mermer İle Mermer Fabrikasından Çıkan Ürünlerin Maliyet Analizi; Barla Mermer Ocağı ve Fabrikası Örneği, EğirdirIsparta. Süleyman Demirel Üniversitesi, Fen Bilimleri Enstitüsü, Yüksek Lisans Çalışmai, 111s, Isparta.

[5] Dereli, M.A., Yalçın, M., Erdoğan, S., 2010. Madencilik Faaliyetlerinde Coğrafi Bilgi Sisteminin Kullanımı. Harita Teknolojileri Elektronik Dergisi, 2, 28-34.

[6] Doğan. T., Özkan, M., Özer, Ü., Kapar, K., Kahriman, A., Erçelebi, S., 2007. Coğrafi Bilgi Sisteminin (CBS) Rezerv Tespitinde Kullanılabilirliği. Yerbilimleri Dergisi, 20, 81-91.

[7] Dumont, J.P., Kerey, E., 1975. Eğirdir Gölü Güneyinin Temel Jeolojik Etüdü. Türkiye Jeoloji Kurumu Bülteni, 18, 160-174.

[8] Earthexplorer, 2018. Erişim Tarihi 02.03.2018 http://earthexplorer.usgs.gov

[9] Efe, U., 2013. Maden İşletmelerinin Planlanmasında Üç Boyutlu Modelleme (3D) ve Coğrafi Bilgi Sistemleri (CBS) Uygulamaları. Dokuz Eylül Üniversitesi, Fen Bilimleri Enstitüsü, Yüksek Lisans Çalışmai, 151s, İzmir.

[10] Francioni, M., Salvini, R., Stead, D., Giovannini, R., Riccucci, S., Vanneschi, C., Gulli, D., 2015. An Integrated Remote Sensing-GIS Approach For The Analysis of an Open Pit In The Carrara Marble District, Italy: Slope Stability Assessment Through Kinematic and Numerical Methods. Computers and Geotechnics, 67, 46-63.

[11] Görmüş, M., Özkul, M., 1995. GönenAtabey(Isparta) ve Ağlasun (Burdur) Arasındaki Bölgenin Statigrafisi. Süleyman Demirel Üniversitesi Fen Bilimleri Enstitüsü Dergisi, 1, 43-64.

[12] Gutnic, M., Monod O., Poisson, A., Dumont, J. F., 1979. Geologie des Taurides occidentales (Turquie). Mem. Soc. Geol. France, 137, 112pp., Paris. 
[13] Hepdeniz, K., 2014. Bucak (Burdur) Mermer Yataklarının Coğrafi Bilgi Sistemleri Kullanılarak Analiz Edilmesi. Süleyman Demirel Üniversitesi, Fen Bilimleri Enstitüsü, Doktora Çalışması, 133s, Isparta.

[14] Jensen, J.R., 2005. Introductory Digital Image Processing: A Remote Sensing Perspective. Pearson Prentice Hall.Earth.

[15] Irlayıcı, A., 1998. Eğirdir-Burdur Arasının Hidrojeoloji İncelemesi. Süleyman Demirel Üniversitesi, Fen Bilimleri Enstitusü, Yüksek Lisans Çalışmai, 150s, Isparta.

[16] Karaman, M.E., Meriç, E., Tansel, İ., 1989. GönenAtabey (Isparta) Arasındaki Bölgenin Jeolojisi. Çukurova Üniversitesi, Mühendislik-Mimarlık Fakültesi Dergisi, Ahmet Acar Sempozyumu. Bildiri Ser: A, Yerbilimleri C:6-7, s:1-2, Kasım 1989-1990, Adana.

[17] Kaya, S., 1999. Uydu Görüntüleri ve Sayısal Arazi Modeli Kullanılarak Kuzey Anadolu Fayı Gelibolu - Işılklar Dağı Kesiminin Jeomorfolojik Jeolojik Özelliklerinin İncelenmesi. İstanbul Teknik Üniversitesi, Fen Bilimleri Enstitüsü, Doktora Çalıșmai, 113s, İstanbul.

[18] Kayadibi, Ö., 2013. Gümüşhane Çevresindeki Hidrotermal Yatakları ve Zenginleşmelerin Uzaktan Algılama ve Coğrafi Bilgi Sistemleri (UA ve CBS) Teknikleri ile İncelenmesi. Ankara Üniversitesi, Fen Bilimleri Enstitüsü, Doktora Çalışmai, 311s, Ankara.

[19] Kızıltaş, M., 2005. İstanbul Bölgesi Taşocaklarının Coğrafi Bilgi Sistemi (CBS) Ortamında Değerlendirilmesi ve Yönetilmesi. İstanbul Üniversitesi, Fen Bilimleri Enstitüsü, Yüksek Lisans Çalışmai, 107s, İstanbul.

[20] Koçyiğit, A., 1983. Hoyran Gölü (Isparta Büklümü) Dolayının Tektoniği. Türkiye Jeoloji Kurumu Bülteni, 26, 1-10.

[21] LANDSAT web sitesi https://landsat.gsfc.nasa.gov/about/technicalinformation /Erișim Tarihi Aralık 2018

[22] MTA web sitesi, 2017. http://www.mta.gov.tr/v3.0/hizmetler / jeolojiharitalari /Erișim Tarihi 05.12.2017

[23] Esri web sitesi, https://www.esri.com/arcgisblog/products/product/imagery/bandcombinations-for-landsat-8/ Erişim Tarihi Aralık 201

[24] MTA doğaltaş veri tabanı https://dogaltas.mta.gov.tr Erişim Tarihi: Aralık 2018.
[25] Poisson, A. 1967. Donnees Nouvelles Sur Le Cretace Superieur Et Le Tertiaire Du Taurus Au NW d'Antalya (Turquie). Compte Rendu Academie Sciences, Paris 264, 2443-2446.

[26] Rouse J.W., Haas R.H., Schell J.A. and Deering D.W., 1973, Monitoring vegetation systems in the Great Plains with ERTS. In 3rd ERTS Symposium, NASA SP-351 I,pp. 309-317.

[27] Sarı, N., 2005. Denizli ve Civarının Jeolojik Özelliklerinin Uzaktan Algılama Yöntemi İle İncelenmesi. Pamukkale Üniversitesi, Fen Bilimleri Enstitüsü, Yüksek Lisans Çalışmai, 72s, Denizli.

[28] Şenel, M., 1997. 1/25.000 Ölçekli Türkiye Jeoloji Haritaları, Antalya paftası, No:3, MTA, Ankara.

[29] Tekin, B.M., Sagular, E,K., 2016. Jeolojik Çözümlemelerde Uydu Görüntüleri Destekli Coğrafi Bilgi Sistemleri; Yeni Foça (İzmir) Yöresi Örneği. Türkiye Jeoloji Bülteni, 59, 27-53.

[30] Uysal, K., 2004. Uzaktan Algılama Landsat MSS ve SPOT XS Uydu Verilerinin Kullanımı İle Ayrıntılı Jeolojik Harita Alımı ve Yorumu: Dereboğazı (Isparta) ve Çevresi Örneği. Süleyman Demirel Üniversitesi, Fen Bilimleri Entitüsü, Yüksek Lisans Çalışmai, 149s, Isparta.

[31] Uysal, K., Görmüş, M., Kresten, J.K., 2008. How can we use Google Earth ${ }^{\circledR}$ as a GIS platform in Geology? Geological pre-mapping example from Lake District, Isparta, SW Turkey. 33rd International Geological Congress, 6-14 Agust 2008, Oslo-Norway.

[32] Uysal, K., 2011. Eğirdir - Burdur Gölleri Çevrelerindeki Pliyo-Kuvaterner Çökellerinin Statigrafik, Sedimantolojik ve Bazı Tektonik Özellikleri. Süleyman Demirel Üniversitesi, Fen Bilimleri Enstitüsü, Doktora Çalıșmai, 272s, Isparta.

[33] Uysal, K., Caran, Ş., 2014. Mermer Ocaklarının Gelişiminin Uzaktan Algllama İle Belirlenmesi: Eğirdir Örneği. Ulusal Mermer ve Taș Ocakları Onarım Teknikleri Sempozyumu, 18-20 Eylül, Isparta, 161-170.

[34] Yakan. M., 2009. Tecer Dağları (Sivas Havzası) Güneyindeki Bölgede Sayısal Jeolojik Harita Alımı ve Bölgenin Aster Uydu Görüntüleri Yardımıyla Jeolojik İncelemesi. Cumhuriyet Üniversitesi, Fen Bilimleri Enstitüsü, Yüksek Lisans Çalıșmai, 76s, Sivas.

[35] Yalçınkaya, S., Ergin, A., Taner, K., Afşar. Ö.P., Dalkılıç, H., Özgönül, E., 1986. Batı Toroslar'ın Jeolojisi. MTA Genel Müd. Raporları Yayınlanmamış, Ankara. 